Adriana de A Paiva'

Patrícia H C Rondó"

Regina A Pagliusi"'

Maria do R D O Latorre $\mathrm{IV}^{\mathrm{V}}$

Maria A A Cardoso'

Sheila S R Gondim'

Núcleo de Estudos e Pesquisas

Epidemiológicas. Universidade Estadual da

Paraíba. Campina Grande, PB, Brasil

Departamento de Nutrição. Faculdade de Saúde Pública (FSP). Universidade de São Paulo (USP). São Paulo, SP, Brasil

III Laboratório de Hemoglobinas. Laboratório Regional de São José do Rio Preto. Instituto Adolfo Lutz. São José do Rio Preto, SP, Brasil

Iv Departamento de Epidemiologia. FSP-USP. São Paulo, SP, Brasi

Correspondence | Correspondência:

Adriana de Azevedo Paiva

Núcleo de Estudos e Pesquisas

Epidemiológicas - UEPB

Av. das Baraúnas, 351

Prédio dos Mestrados $-2^{\circ}$ Andar Bodocongó

58100-001 Campina Grande, PB, Brasil

E-mail: aapaiva@yahoo.com.br

\section{Relationship between the iron status of pregnant women and their newborns}

\section{Relação entre o estado nutricional de ferro de parturientes e seus recém- nascidos}

\begin{abstract}
OBJECTIVE: To determine the relationship between iron nutritional status of pregnant women and their newborns using a combination of hematological and biochemical parameters for the diagnosis of iron deficiency.

METHODS: A cross-sectional study was conducted in Jundiaí, Southeastern Brazil, in 2000. Venous blood samples collected from 95 pregnant women and from their umbilical cord and used for the determination of complete blood count, serum iron, total iron-binding capacity, serum ferritin, zinc protoporphyrin, and transferrin saturation. Women were classified into three groups: anemic, iron deficient and non-iron deficient. Statistical analysis included the Tukey-HSD test, Pearson's correlation coefficient and multiple linear regression analysis.
\end{abstract}

RESULTS: Among pregnant women, $19 \%$ were anemic $(97.9 \%$ mildly anemic and $2.1 \%$ moderately anemic) and $30.5 \%$ were iron deficient. No significant difference was seen in mean values of any parameter studied between newborns in the three groups $(p>0.05)$. Multiple linear regression analysis showed weak association between neonatal and maternal parameters.

CONCLUSIONS: The iron nutritional status of pregnant women with iron deficiency or mild anemia does not seem to have a significant impact on the iron levels of their children.

KEYWORDS: Nutritional status. Pregnant women. Infant, newborn, growth \& development. Iron deficiency, blood. Anemia. Maternal-fetal exchange. 


\section{RESUMO}

OBJETIVO: Determinar a relação entre os níveis de ferro de gestantes e seus filhos recém-nascidos, utilizando uma combinação de parâmetros hematológicos e bioquímicos para o diagnóstico da deficiência de ferro.

MÉTODOS: Estudo transversal realizado em Jundiaí, SP, em 2000. Amostras de sangue venoso foram coletadas de 95 gestantes e do cordão umbilical de cada uma, e utilizadas na determinação de hemograma completo, ferro sérico, capacidade total de ligação do ferro, ferritina sérica, zinco-protoporfirina, e saturação de transferrina. As mulheres foram classificadas em três grupos: anêmicas, deficientes de ferro e não-deficientes de ferro. As análises estatísticas utilizadas foram o teste de Tukey-HSD, o coeficiente de correlação de Pearson e regressão linear múltipla.

RESULTADOS: Entre as gestantes, 19\% estavam anêmicas (97,9\% levemente anêmicas e 2,1\% moderadamente anêmicas) e 30,5\% apresentavam deficiência de ferro. Não foi observada diferença significativa nas médias dos valores dos parâmetros estudados nos recém-nascidos dos três grupos $(\mathrm{p}>0,05)$. A análise de regressão linear múltipla mostrou fraca associação entre os parâmetros maternos e neonatais.

CONCLUSÕES: Os níveis de ferro de gestantes com deficiência de ferro ou com anemia leve/moderada parecem não influenciar de forma significativa os níveis de ferro de seus filhos.

\section{DESCRITORES: Estado nutricional. Gestantes. Recém-nascido, crescimento \& desenvolvimento. Deficiência de ferro, sangue. Anemia. Troca materno-fetal.}

\section{INTRODUCTION}

Iron deficiency anemia is the most frequent nutritional deficiency in pregnancy, with an impact on maternal and fetal morbidity and mortality. It is regarded as the most important preventable cause of perinatal complications, such as premature delivery, intrauterine growth retardation and neonatal and perinatal death. ${ }^{1,20}$

It is still not clear whether iron deficiency in pregnant women might lead to a deficient iron status of their children. Many studies have supported the belief that iron transport from the mother to their fetus occurs independently of maternal iron levels, and that it might even induce deficiency in the mother as a result of fetal "parasitism". ${ }^{9,13,18}$ However, later studies have questioned this belief and suggested that maternal iron deficiency can cause depletion of fetal iron stores. ${ }^{3,8,14,16,17}$ No consensus regarding this subject has been reached thus far.

The difficulty in establishing a precise diagnosis of the iron status of pregnant women represents a complicating factor in the understanding of the relationship between maternal and fetal iron levels. The physiological changes that occur during pregnancy (increased plasma volume and erythropoiesis) have a significant impact on hematological and biochemical parameters available for the assessment of iron status. Hemoglobin concentration is the most used parameter to detect anemia in public health care services due to its low cost and available reference standards. Therefore, a combination of several parameters has been proposed in order to improve the diagnosis of iron deficiency. ${ }^{5,23}$

The objective of the present study was to determine the relationship between the iron status of pregnant women and their newborns using a combination of several hematological and biochemical parameters for the diagnosis of iron deficiency.

\section{METHODS}

A cross-sectional study was conducted including pregnant women/newborn pairs from two public hospitals in Jundiaí, Southeastern Brazil. All pregnant women had single children born at term (37 to 42 weeks) as determined by the method of Capurro et al, ${ }^{4}$ performed by a trained researcher and confirmed by medical examination. Women with systemic diseases (toxemia, hypertension, diabetes mellitus, and heart disease) were not included in the study. 
The sample size $(\mathrm{N}=130)$ was estimated using the t-test table to compare means of continuous variables ${ }^{7}$ at $\alpha=1 \%$ and $\beta=5 \%$, and considering $30 \%$ for the prevalence of anemia in pregnant women and $10 \%$ to compensate for possible losses. There were first studied 135 pregnant women: 23 had hemolytic blood or insufficient blood volume; 15 women had hemoglobinopathies and thalassemia, determined by hemoglobin electrophoresis at $\mathrm{pH} 8.6$ and measurement of fetal hemoglobin; and two had postpartum complications. Therefore, the final sample comprised 95 pregnant women/newborn pairs.

Venous blood samples were collected by a trained researcher from pregnant women during labor and from their umbilical cord immediately after clamping into Vacutainer tubes containing EDTAK $_{3}$ as anticoagulant and into tubes without anticoagulant (Becton Dickinson Vacutainer System, USA). The following hematological and biochemical parameters were determined: 1) complete blood count using the Cell Dyn 3000 automated counter (Abbott, USA), 2) serum iron determined by a colorimetric method using the Synchron CX system (Beckman, USA), 3) total iron-binding capacity determined by a turbidimetric method using the Cobas Mira Plus system (Roche, USA), 4) serum ferritin measured by chemiluminescence in an Immulite apparatus (Immulite, DPC, USA), and 5) zinc protoporphyrin (ZPP) measured with a Protofluor $Z$ hematofluorometer (Helena Laboratories, Beaumont, TX). Transferrin saturation was estimated based on the ratio between serum iron and total iron-binding capacity.

Pregnant women were divided into three groups: 1) anemic, 2) iron deficient, and 3) non-iron deficient. A combination of hematological and biochemical parameters (hemoglobin, ferritin, transferrin saturation and ZPP) was used for the classification of the three groups according to the model proposed by Cook \& Finch. ${ }^{5}$ Pregnant women showing low hemoglobin levels $(<11 \mathrm{~g} / \mathrm{dL})$ and with at least one of the other parameters altered (ferritin $<10 \mu \mathrm{g} / \mathrm{dL}$ or transferrin saturation $<16 \%$ or ZPP $>60 \mu \mathrm{mol} / \mathrm{mol}$ heme) were considered to be anemic. Pregnant women with normal hemoglobin values $(\geq 11 \mathrm{~g} / \mathrm{dL}$ ) and with at least two of the other parameters altered were classified as iron deficient, and those with a maximum of one altered parameter (except for hemoglobin) were considered to be non-iron deficient.

The EpiInfo and Statistica software programs were used for statistical analysis. Differences in mean parameters between the women and their newborns in the three groups were determined by two-factor analysis of variance, with "group" being one factor and "pregnant women and newborn" the other factor. Multiple comparison analyses were performed by the Tukey-HSD test. The assumption of normality was tested by the Kolmogorov-Smirnov test, with the variables ferritin, ZPP and serum iron not showing a normal distribution and therefore being converted into a logarithmic scale before statistical analysis. Pearson's correlation coefficient was used for correlation analysis. Multiple linear regression analysis was applied to determine whether newborn parameters could be explained by maternal parameters. A p-value $<0.05$ was considered to be significant for all tests.

The research protocol was approved by the Ethics Committee of the Faculdade de Saúde Pública, Universidade de São Paulo, and the women signed an informed consent form agreeing to participate.

\section{RESULTS}

Nineteen percent (19\%) of the pregnant women studied were anemic, 30.5\% were iron deficient and 50.5\% were non-iron deficient. It should be emphasized that among anemic women, $33.3 \%$ did not take any iron supplements during pregnancy, while $66.7 \%$ did so during at least one trimester of gestation. Among iron deficient pregnant women, $14.3 \%$ did not use any iron supplements and $85.7 \%$ took supplements during at least one trimester. In contrast, only $8.3 \%$ of noniron deficient pregnant women did not take any iron supplements, while $91.7 \%$ used supplements during at least one trimester.

Table 1 shows the characteristics of pregnant women and their newborns in the three groups studied, showing no significant differences in the variables studied.

Table 1. Age and obstetric characteristics of pregnant women and birth weight of newborns (mean and SD) according the iron status of the women (anemic, iron deficient and non-iron deficient). Southeastern Brazil, 2000.

\begin{tabular}{lccc}
\hline Characteristic & Anemic $(\mathrm{N}=18)$ & Iron deficient $(\mathrm{N}=29)$ & Non-iron deficient $(\mathrm{N}=48)$ \\
\hline Age (years) & \multicolumn{2}{c}{ Group mean (SD) } \\
Parity & $2.1(1.6)$ & $23.1(4.4)$ & $24.8(6.0)$ \\
Gestational interval (years) & $1.4(1.8)$ & $2.2(1.3)$ & $2.3(1.5)$ \\
Gestational age (weeks) & $38.9(1.4)$ & $3.1(3.1)$ & $2.6(2.8)$ \\
Birth weight (g) & $3,202(465)$ & $38.8(1.2)$ & $39.3(1.0)$ \\
\hline
\end{tabular}

SD: standard deviation 

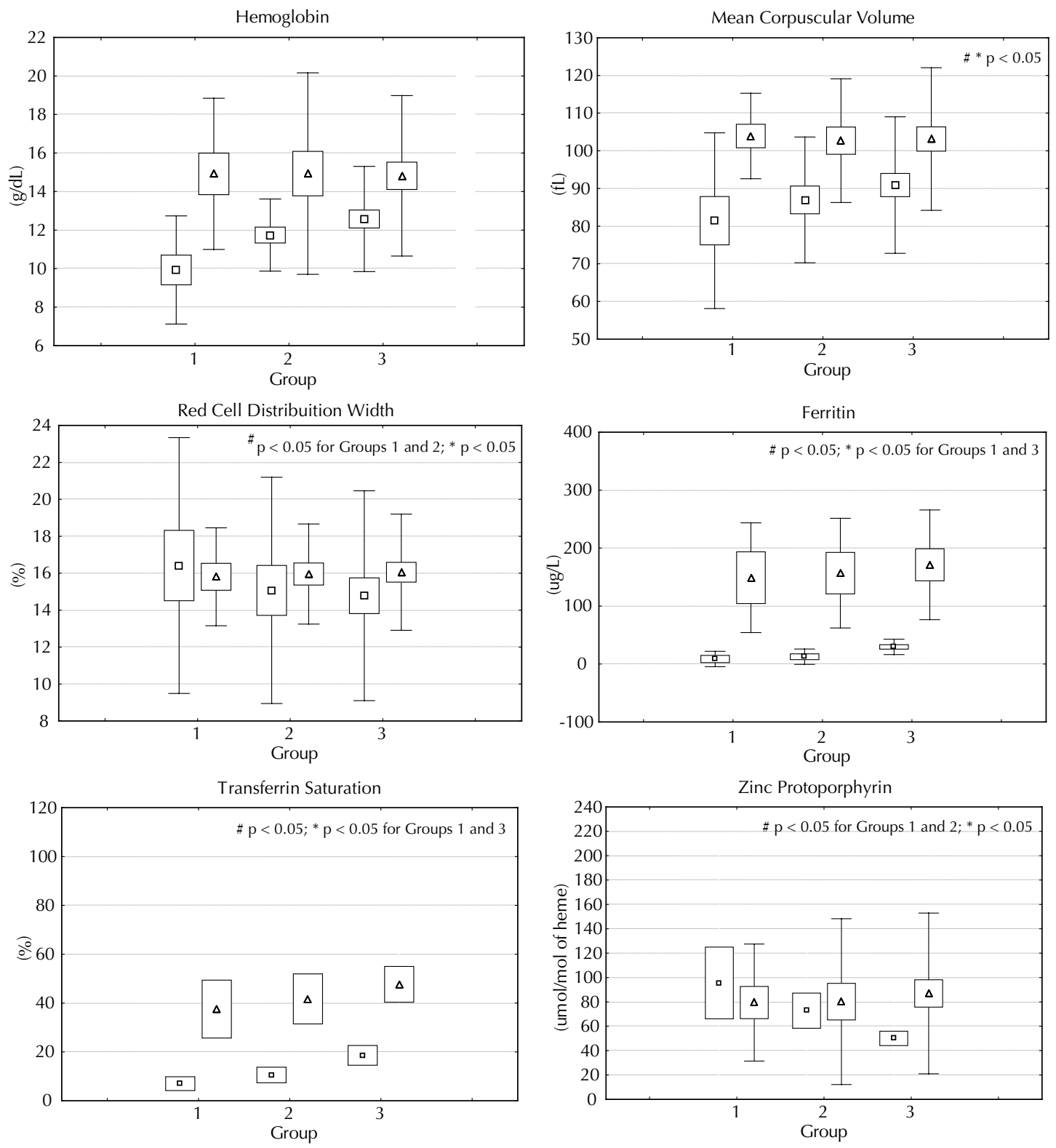

\section{Group:}

1. Anemic $(\mathrm{N}=18)$

2. Iron deficient $(\mathrm{N}=29)$

3. Non-iron deficient $(\mathrm{N}=48)$

\# Mean difference (Tukey-HSD test) between parameters of pregnant women ( $\square, N=95)$ and newborns $(\Delta, N=95)$.

* Mean difference (Tukey-HSD test) between parameters of pregnant women ( $\square, N=95)$ in groups 1, 2 and 3.

Figure. Boxplots of hematological parameters in pregnant women and newborns according to the iron status of the women (anemic, iron deficient and non-iron-deficient). Southeastern Brazil, 2000.

The distribution of the hematological and biochemical parameters of maternal and umbilical cord blood is shown in Figure. Comparison of these parameters in each group revealed significantly higher values for umbilical cord blood than for maternal blood $(\mathrm{p}<0.05)$, except for red cell distribution width (RDW) and ZPP. Higher RDW and ZPP values in cord blood were only seen in the non-iron deficient group $(\mathrm{p}<0.05)$.
Comparison of the variables between anemic, irondeficient and non-iron deficient pregnant women showed a gradual decline in both hematological and biochemical parameters according to the course of iron deficiency (except for RDW and ZPP which tended to increase). Furthermore, no significant differences $(p>0.05)$ in ferritin levels or transferrin saturation were seen between anemic and iron-deficient women (Figure). With respect to parameters determined in 
Table 2. Pearson's correlation coefficients ( $r$ ) between iron parameters of pregnant women and their respective newborns. Southeastern Brazil, 2000.

\begin{tabular}{lcccccccc}
\hline $\begin{array}{l}\text { Iron parameters of } \\
\text { pregnant women }\end{array}$ & \multicolumn{9}{c}{ Iron parameters of newborns } \\
& Hemoglobin & MCV & RDW & Ferritin & ZPP & Serum iron & TIBC & TS \\
\hline Hemoglobin & 0.08 & 0.03 & 0.01 & 0.04 & 0.08 & 0.02 & 0.01 & -0.03 \\
MCV & 0.04 & 0.01 & 0.07 & 0.13 & 0.10 & 0.17 & 0.03 & 0.08 \\
RDW & -0.01 & -0.09 & 0.19 & -0.16 & 0.08 & -0.19 & 0.07 & -0.18 \\
Ferritin & 0.05 & -0.05 & 0.02 & 0.07 & 0.10 & 0.00 & -0.02 & -0.02 \\
ZPP & 0.08 & 0.08 & 0.01 & $-0.23^{*}$ & 0.04 & -0.13 & 0.17 & -0.15 \\
Serum iron & 0.00 & -0.11 & -0.06 & 0.04 & 0.10 & $0.26^{*}$ & -0.08 & 0.20 \\
TIBC & -0.05 & -0.01 & $0.20^{*}$ & -0.07 & 0.15 & 0.05 & $0.42^{*}$ & -0.12 \\
TS & 0.06 & -0.04 & 0.05 & -0.07 & -0.03 & $0.22^{*}$ & $-0.23^{*}$ & $0.23^{*}$ \\
\hline
\end{tabular}

$* \mathrm{p}<0.05$

MCV: Mean Corpuscular Volume; RDW: Red Cell Distribution Width; ZPP: Zinc Protoporphyrin; TIBC: Total Iron Binding Capacity; TS: Transferrin Saturation

Table 3. Associations between iron parameters in pregnant women and their newborns assessed by multiple linear regression analysis. Southeastern Brazil, 2000.

\begin{tabular}{lcc}
$\begin{array}{l}\text { Variable of } \\
\text { newborns }\end{array}$ & $\begin{array}{c}\text { Model including the variables } \\
\text { hemoglobin, ferritin, TS and ZPP of } \\
\text { pregnant women }\end{array}$ \\
& $\mathrm{r}^{2}$ & p-value \\
\hline Hemoglobin & 0.01 & 0.74 \\
Ferritin & 0.08 & 0.08 \\
TS & 0.05 & 0.02 \\
ZPP & 0.03 & 0.46 \\
\hline
\end{tabular}

TS: Transferrin Saturation; ZPP: Zinc Protoporphyrin.

umbilical cord blood, no significant difference in any of the parameters was seen in children born to anemic, iron deficient and non-iron deficient pregnant women $(\mathrm{p}>0.05)$ (Figure). There were found only weak, mostly non-significant, correlations between biochemical and hematological parameters in newborn and maternal blood (Table 2).

Multiple linear regression analysis showed that the parameters seen in newborn children (hemoglobin, ferritin, ZPP and transferrin saturation) could not be explained as a function of the same maternal parameters. As shown in Table 3, only the model considering newborn transferrin saturation as the dependent variable had a statistically significant association with other maternal parameters; however, the low $r^{2}$ value obtained suggests that this association was probably a random event.

\section{DISCUSSION}

Iron deficiency is the most common nutritional deficiency in pregnancy and has an important impact on maternal and fetal morbidity and mortality. In the present study, practically half of the pregnant women studied had at any stage iron deficiency even if anemia had not been manifested. The prevalence of iron deficiency was very high, especially given that this condition can be prevented by dietary guidance in combination with the use of iron supplements during pregnancy. The present results show that the prevalence of anemia and iron deficiency were markedly lower when the mother took iron supplements during at least one trimester of gestation.

Various studies have been carried out to determine the relationship between anemia and iron deficiency in pregnant women and their newborns, but the results are inconsistent and inconclusive. It has been currently discussed whether maternal iron nutritional status has an impact or not on the iron status of their children at birth and throughout childhood. ${ }^{10,11,13,14,21,22,24}$

It is known that the fetus receives iron indirectly from the maternal circulation through a rapid and unidirectional process. Maternal iron is transported to the placenta bound to a protein, maternal transferrin, which does not cross the placenta, transferring this mineral element to placental receptors. Iron then binds to a protein with the same structure, fetal transferrin, and is transported through the bloodstream to fetal tissues. ${ }^{15}$ In general, iron-related hematological and biological parameters are markedly higher in umbilical cord than maternal blood. ${ }^{15,19}$ The present study corroborates this observation for most of the parameters studied. However, ZPP values would be expected to be higher in maternal than cord blood, since this parameter shows an inversely proportional relationship to body iron levels. Yet ZPP levels were significantly higher in newborns, whereas normal levels were found in the pregnant women. One possible explanation is the fact that, according to some authors, ${ }^{2,12}$ this parameter is invariably increased in newborns irrespective of their iron levels. 
In the present study, all parameters analyzed were statistically similar in children born to anemic, iron deficient and non-iron deficient pregnant women. This result suggests that maternal iron nutritional status at the end of pregnancy does not have an impact on iron levels of the newborn. Although not significant, the biochemical parameters analyzed showed a discrete and gradual increase as the iron nutritional status of pregnant women improved. Other investigators also did not find significant differences between children born to anemic or iron-deficient pregnant women and those born to normal pregnant women. ${ }^{9-11,13,18}$

In a case-control study carried out in Jordan, Kilbride et $\mathrm{al}^{11}$ investigated the relationship between maternal anemia and iron status of newborns at birth (umbilical cord) and at 3-4, 6, 9 and 12 months of age. The authors found that iron content in cord blood was similar in anemic and control pregnant women, with no significant difference in hemoglobin, hematocrit, mean corpuscular volume, mean corpuscular hemoglobin, mean corpuscular hemoglobin concentration or plasma ferritin. However, the rate of anemia was higher in children born to anemic pregnant women than in those born to non-anemic pregnant women at 3-4 (6\% vs. $1 \%), 6(43 \%$ vs. $28 \%), 9(68 \%$ vs. $48 \%)$ and 12 months of age ( $81 \%$ vs. $65 \%)$. According to other investigators, maternal anemia is an important risk factor that can trigger anemia during infancy, even if no differences in hematological or biochemical parameters are seen in newborns at birth.

It should be emphasized that no case of severe anemia was identified in the present study, with anemia being classified based on criteria of the World Health Organization, ${ }^{6}$ which considers individuals with hemoglobin concentrations lower than $7 \mathrm{~g} / \mathrm{dL}$ to be severely anemic. In the present study, $97.9 \%$ of the pregnant women had hemoglobin levels higher than $9 \mathrm{~g} / \mathrm{dL}$. In view of this fact, one may suppose that in cases of severely anemic pregnant women their newborn's iron levels at birth might be significantly compromised.

In the present study, weak correlations were found between the hematological parameters of newborns and their mothers. Several investigators have determined the correlation between some of these parameters; however, the results vary from study to study probably because of the low specificity of most parameters, which can be altered by different conditions, including sub-clinical infections. Rios et al, ${ }^{18}$ Kelly et $\mathrm{al}^{9}$ and Puolakka et $\mathrm{al}^{17}$ did not find any correlation between maternal and umbilical cord ferritin levels. Lao et $\mathrm{al}^{13}$ reported a correlation between maternal mean corpuscular volume and mean corpuscular hemoglobin and cord serum iron $(\mathrm{r}=0.24$ and $\mathrm{r}=0.25$, respectively).

The multivariate regression analysis confirmed the weak correlation between newborn and maternal parameters and suggested that the hematological and biochemical parameters of children born to mildly or moderately anemic pregnant women cannot be predicted on the basis of maternal parameters. These results suggest that the fetus is able to maintain adequate iron levels even when their mother has iron deficiency or mild anemia. However, this behavior might be altered in cases of severely anemic pregnant women. In addition, anemia or iron deficiency during pregnancy has been suggested to have an impact on the nutritional status of children only after the first months of life, even when no significant compromise is seen at birth.

Therefore, studies investigating the different stages of anemia are needed, especially moderate and severe disease, with follow-up of children from birth to at least six months of age.

\section{ACKNOWLEDGEMENTS}

To Dr. Maria Isabel Sciamarelli, of the Hospital São Vicente de Paula Laboratory, for performing the clinical analyses. 


\section{REFERENCES}

1. Allen LH. Pregnancy and iron deficiency: unresolved issues. Nutr Rev. 1997;55(4):91-101.

2. Bartels PC, Helleman PW, Soons JBJ. Changes in size and zinc protoporphyrin/haemoglobin ratio in red cells of infants during the first months of life. Ann Clin Biochem. 1990;27(Pt2):102-6.

3. Bhargava M, Iyer PU, Kumar R, Ramji S, Kapani V, Bhargava SK. Relationship of maternal serum ferritin with foetal serum ferritin, birth weight and gestation. J Trop Pediatr. 1991;37(4):149-52.

4. Capurro H, Konichezky S, Fonseca D, Caldeiro-Barcia R. A simplified method for diagnosis of gestational age in the newborn infant. J Pediatr. 1978;93(1):120-2.

5. Cook JD, Finch CA. Assessing iron status of a population. Am J Clin Nutr. 1979;32(10):2115-9.

6. DeMaeyer EM, Dallman P, Gurney JM, Hallberg L, Sood SK, Srikantia SG. Preventing and controlling iron deficiency anaemia through primary health care: a guide for health administrators and programme managers. Geneva: World Health Organization; 1989.

7. Hokama T, Takenaka S, Hirayama K, Yara A, Yoshida K, Itokazu K, et al. Iron status of newborns born to iron deficient mothers. J Trop Pediatr. 1996;42(2):75-7.

8. Hulley SB, Cummings SR, Browner WS, Grady DG, Newman TB. Design clinical research: an epidemiological approach. Baltimore: Lippincott Williams \& Wilkins; 1988.

9. Kelly AM, Macdonald DJ, McDougall AN. Observations on maternal and fetal ferritin concentrations at term. Br / Obstet Gynaeco. 1978;85(5):338-43.

10. Kilbride J, Baker TG, Parapia LA, Khoury SA. Incidence of iron-deficiency anaemia in infants in a prospective study in Jordan. Eur J Haematol. 2000;64(4):231-6.

11. Kilbride J, Baker TG, Parapia LA, Khoury SA, Shuqaidef SW, Jerwood D. Anaemia during pregnancy as a risk factor for iron-deficiency anaemia in infancy: a case-control study in Jordan. Int J Epidemiol. 1999;28(3):461-8.

12. Labbe RF, Rettmer RL. Zinc protoporphyrin: a product of iron-deficient erythropoiesis. Semin Hematol. 1989;26(1):40-6.
13. Lao TT, Loong EP, Chin RK, Lam CW, Lam YM. Relationship between newborn and maternal iron status and haematological indices. Biol Neonate. 1991;60(5):303-7.

14. Olivares M, Llaguno S, Marin V, Hertrampf E, Mena P, Milad M. Iron status in low-birth-weight infants, small and appropriate for gestational age. A follow up study. Acta Paediatr. 1992;81(10):824-8.

15. Oski FA, Naiman JL, Stockman JA. Hematologia do recém-nascido. São Paulo: Manole; 1984.

16. Picciano MF. Embarazo y lactancia. In: Zieglery EE, Filer LJ Jr, editores. Conocimientos actuales sobre nutrición. 7. ed. Washington (DC): OPS; 1997. p. 41022. (OPS - Publicación Científica, 565).

17. Puolakka J, Jänne O, Vihko R. Evaluation by serum ferritin assay of the influence of maternal iron stores on the iron status of newborns and infants. Acta Obstet Gynecol Scand Suppl. 1980;95:53-6.

18. Rios E, Lipschitz DA, Cook JD, Smith NJ. Relationship of maternal and infant iron stores as assessed by determination of plasma ferritin. Pediatrics. 1975;55(5):694-9.

19. Rondó PHC, Abbott R, Rodrigues LC, Tomkins AM. Vitamin A, folate, and iron concentrations in cord and maternal blood of intra-uterine growth retarded and appropriate birth weight babies. Eur J Clin Nutr. 1995;49(6):391-9.

20. Scholl TO. Iron status during pregnancy: setting the stage for mother and infant. Am J Clin Nutr. 2005;81(5):1218S-1222S.

21. Singla PN, Tyagi M, Kumar A, Dash D, Shankar R. Fetal growth in maternal anaemia. J Trop Pediatr. 1997;43:89-92.

22. Toure-Fall AO, Gadji M, Diop S, Dieye T, Thiam D, Diakhare L. Maternal anaemia: effect on the newborn. Dakar Med. 2004; 49(3):172-6.

23. Van Den Broek NR, Letsky EA, White AS, Shenkin A. Iron status in pregnant women: which measurements are valid? Br J Haematol. 1998;103(3):817-24.

24. Zhou LM, Yang WW, Hua JZ, Deng CQ, Tao X, Stoltzfus RJ. Relation of hemoglobin measured at different times in pregnancy to preterm birth and low birth weight in Shangai, China. Am J Epidemiol. 1998;148(10):998-1006. 